\title{
"Third wave" of COVID-19 Pandemic in Hong Kong
}

\author{
Siukan Law ${ }^{1}$, Albert Wingnang Leung ${ }^{2}$, Chuanshan $\mathrm{Xu}^{3}$
}

\begin{abstract}
${ }^{1}$ Department of Science, School of Science and Technology, The Open University of Hong Kong, Ho Man Tin, Kowloon, Hong Kong; ${ }^{2}$ School of Graduate Studies, Lingnan University, Tuen Mun, Hong Kong; ${ }^{3}$ Key Laboratory of Molecular Target and Clinical Pharmacology, State Key Laboratory of Respiratory Disease, School of Pharmaceutical Sciences \& Fifth Affiliated Hospital, Guangzhou Medical University, Guangzhou 511436, China
\end{abstract}

[Received: 17 August 2020; Accepted: 28 September 2020]

COVID-19 pandemic seems to be stabilized during the previous month with no local case and foreign input cases only. However, there was a 59-year-old chef local case discovered in Kwun Tong Hong Kong on the $6^{\text {th }}$ of July recently. He has been identified as the $1,269^{\text {th }}$ patient infected with COVID-19, no travel history and a serious number of infected cases proportionally increased later on. The number of local confirmed cases become more than double in a week from the $6^{\text {th }}$ to $12^{\text {th }}$ of July ${ }^{1}$ (Figure I). Is this "community outbreak"? The third wave of COVID-19 epidemic in Hong Kong.

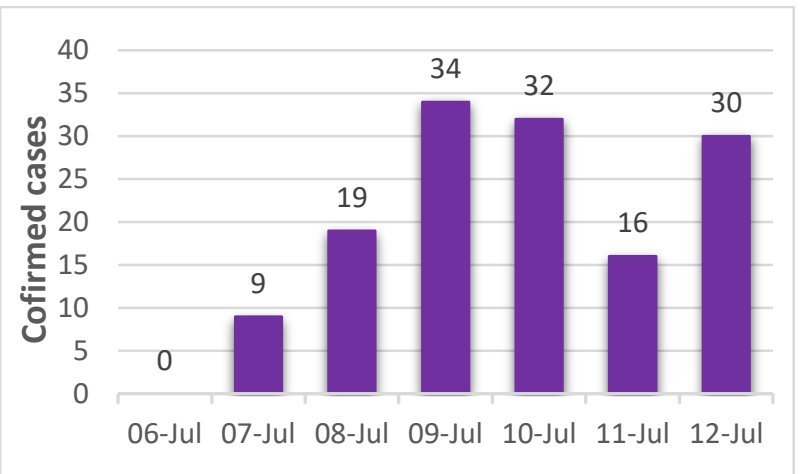

Figure I: The number of local confirmed cases in Hong Kong from the $6^{\text {th }}$ to $12^{\text {th }}$ of July. (Data collected and analysed from the Centre for Health Protection, Department of Health, The Government of the Hong Kong Special Administrative Region)

Any corresponding health policy be implemented? In early $29^{\text {th }}$ of March 2020, the Hong Kong Chief Executive and its Council were legislated "Prevention and Control of Disease (Prohibition on Group Gathering) Regulation", from the Prevention and Control of Disease Ordinance (Cap. 599) under section $8^{2}$. It's including group gathering can't more than 50 persons and four persons only for meal per table. The table should be separated by at least 1.5 meters or blocked by a clapboard to keep a social distance and must wear a mask when taking public transportation. These are focusing on the COVID-19 infection chain-breaking. Based on the confirmed case, it has been indicated that the indoor spread of SARS-CoV-2 in a restaurant is indisputable as the transmission of COVID-19 via respiratory droplets within a short distance of $2 \mathrm{~m}$ and human-to-human transmission or by contaminated surfaces leading to infection through contact ${ }^{3}$. If air is not circulating and the place is crowded, its virus easily existing in the air and infected to the respiratory tract for replication. Although the restaurant has a clapboard to isolate customers from each other, this is not enough to block the spread of the virus, so it's better to take away and reduce eating out. On the $13^{\text {th }}$ of July, the Hong Kong government tighten the regulation with effective from $15^{\text {th }}$ of July e.g. group gathering must less than 20 persons, and ban the dining for anyone in catering industry after six o'clock at night. It's further measures and to be adopted to maintain social distancing ${ }^{4}$.

Besides, there were several infection cases with no clinical symptoms in homes for the aged. As the elderly immune system normally is not good, so when visitors and staffs infected with COVID-19, it increases the risk of infection to other elderly especially underlying medical conditions consist of chronic lung disease, immunocompromising conditions and diabetes. This must break the continuous infection chain, e.g. personal hygiene and maintain a physical distance for the elderly, 
otherwise, the aged centre would be a small outbreak ${ }^{5}$.

According to the re-emerge infection cases in the past week, asymptomatic patients may have existed and its latent period is around 14 days or imported the infection cases. Therefore, some infection sources of COVID-19 cannot be found and tracked. The transmission chain of COVID-19 has never been broken and its pandemic rebound again in Hong Kong. Everyone should be vigilant, pay more attention to the rules of social distance and personal hygiene, do not slacken to fight against COVID-19. The SARS-CoV-2 in COVID-19 would become difficult to measure because of the mutation, it has a higher transmission rate from human-to-human. If ignored these prevention and control guidelines of COVID-19, Hong Kong will face more challenges after the following days, more infection and confirmed cases appeared.

\section{References}

1. Centre for Health Protection, Department of Health, The Government of the Hong Kong Special Administrative Region. Press Releases. 6-12 July 2020; Available from: https://www.chp.gov.hk/en/index.html; Accessed 13 Jul 2020

2. Hong Kong e-Legislation. Cap. 599G Prevention and Control of Disease (Prohibition on Group Gathering) Regulation. 29th March 2020; Available from: https://www.elegislation.gov.hk/hk/cap599G; Accessed 13 Jul 2020

3. Peng PWH, Ho PL, Hosta SS. Outbreak of a new coronavirus: what anaesthetists should know. Br J Anaesth 2020
4. The Hong Kong Government. Government further tightens social distance measures. 13 July 2020. Available from: https://www.info.gov.hk/gia/general/202007/14/P20200714000 10.htm?fontSize=1; Accessed 13 Jul 2020

5. Cheung E. Coronavirus: guidelines to keep Hong Kong elderly care homes free of disease must be made mandatory, experts say. 10 July 2020; Available from: https://www.scmp.com/news/hong-kong/healthenvironment/article/3092571/coronavirus-guidelines-keephong-kong-elderly; Accessed 13 Jul 2020

[Bangladesh Journal of Infectious Diseases, October 2020;7(suppl_2):S61-S62]

Correspondence: Dr. Siukan Law, Department of Science, School of Science and Technology, The Open University of Hong Kong, Ho Man Tin, Kowloon, Hong Kong; Email: siukanlaw@hotmail.com

Conflict of interest: The authors have no conflicts of interest to disclose.

Funding agency: The authors received no funding source/grants or other materials support for this work.

Contribution to authors: All authors contributed to the concept, acquisition and analysis of data, drafting of the manuscript, and critical revision of the manuscript for important intellectual content. All authors had full access to the data, contributed to the study, approved the final version for publication, and take responsibility for its accuracy and integrity.

How to cite this article: Law S, Leung AW, Xu C. "Third wave" of COVID-19 Pandemic in Hong Kong. Bangladesh J Infect Dis 2020;7(suppl_2):S61-S62

Copyright: $\odot 2020$. Law et al. Published by Bangladesh Journal of Infectious Diseases. This article is published under the Creative Commons CC BY-NC License (https://creativecommons.org/licenses/by-nc/4.0/). This license permits use, distribution and reproduction in any medium, provided the original work is properly cited, and is not used for commercial purposes. 